\title{
Formation of Anisotropic Tl-1212, Tl-2212, Tl-1223 and Tl-2223 Particles using Aerosol Flow Reacted Powders
}

\author{
M. Paranthaman', A. Goyalb, D. E. Heatherlya , and D. M. Kroegerb \\ ${ }^{a}$ Chemical and Analytical Sciences Division, Oak Ridge National Laboratory, Oak Ridge, TN 37831-6100 \\ bMetals and Ceramics Division, Oak Ridge National Laboratory, Oak Ridge. TN 37831-6116
}

\begin{abstract}
Highly anisotropic particles of T1-1212, T1-2212, Tl-1223 and Tl-2223 superconductors were grown. The Tl-free precursor powders with the compositions $\mathrm{Ba}_{1} \mathrm{Ca}_{2} \mathrm{Cu}_{3} \mathrm{Ag}_{0.37} \mathrm{O}_{6}$ and $\mathrm{Ba}_{2} \mathrm{Ca}_{2} \mathrm{Cu}_{3} \mathrm{Ag}_{\mathrm{B}_{3}} \mathrm{O}_{7}$ were prepared using an aerosol now reactor. These precursor powders were then post-annealed in $0.1 \mathrm{~atm}$ oxygen at $700^{\circ} \mathrm{C}$ for $4 \mathrm{~h}$ to reduce the carbon present and mbxed with $\mathrm{Tl}_{2} \mathrm{O}_{3}$ (typlcal composition of $\left.\mathrm{Tl}_{3} ; \mathrm{x}=0.6-1.0\right)$. The Tl-contalning powders were heated in sealed gold tubes between $650-890^{\circ} \mathrm{C}$ for various times. $\mathrm{X}$-ray diffraction showed that the TI-2212 and T1-2223 phases were stable over a wide range of temperatures. Scanning electron microscopy showed evidence for the presence of bigh aspect-rat lo partlcles. These highly anisotropic particles may of interest for the preparation of powder-In-tube and other powder deposited conductors, for current leads, and for grain alignment studics.
\end{abstract}

\section{INTRODUCTION}

The observation of high critical currents and good "infield" transpor property measurements at temperatures $>40$ $\mathrm{K}$ in $\mathrm{TlBa}_{2} \mathrm{Ca}_{2} \mathrm{Cu}_{3} \mathrm{O}_{9}$ or $(\mathrm{Tl}, \mathrm{Pb})(\mathrm{Sr}, \mathrm{Ba})_{2} \mathrm{Ca}_{2} \mathrm{Cu}_{3} \mathrm{O}_{9}$ (both referred to as $\mathrm{Tl}$-1223) superconductors give these materials great tecbnological importance for $40 \mathrm{~K}$ applications [1]-[4]. For the fabrication of superconducting wires, tapes, powderdeposited conductors and magnetic shields, fine homogeneous precursor powders are necessary. A promising method for producing superconducting powders is the gasphase decomposition of aerosol droplets containing inorganic precursors [5]. The aerosol pyrolysis technique can produce high quality powders with reproducible phase content, particle morphology, size distribution and microstructure, but synthesis of complex oxide aerosol precursor powders and their subsequent thallination require studies of grain growth, chemical reactions and phase transitions during processing. In this work, we report the formation of submicron size particles of precursor powders by

Manuscript recejved October 17, 1994.

This u'ork was sponsored by the Division of Materials Sciedces, Office of Basic Energy Sciences, US Department of Energy and technology development was funded by the US Department of Energy Office of Advanced Utility Conoept-Superconductor Technology Program, boxh under contract DE-ACOS-840R21400 with Marin Marietta Energy Systems, Inc. This work was also supported by the Oak Ridge National Laboratory Postdoctoral Research Program, administered jointly by the ORISE and ORNL. aerosol decomposition of the starting nominal compositions $\mathrm{Ba}_{2} \mathrm{Ca}_{2} \mathrm{Cu}_{3} \mathrm{Ag}_{0.37} \mathrm{O}_{7}$ and $\mathrm{Ba}_{1} \mathrm{Ca}_{2} \mathrm{Cu}_{3} \mathrm{Ag}_{0.37} \mathrm{O}_{6}$. These precursor powders were then mixed stoichiometrically with $\mathrm{T}_{2} \mathrm{O}_{3}$, and heat-treated at various temperatures and different periods of times in sealed gold tubes. Highly anisotropic particles of $\mathrm{Tl}-2212, \mathrm{~T}-2223, \mathrm{~T} 7-1212$ and $\mathrm{Tl}-1223$ superconductors were obtained at different temperatures.

\section{EXPERMMENTAL ASPECTS}

Precursor powders with the nominal compositions $\mathrm{Ba}_{2} \mathrm{Ca}_{2} \mathrm{Cu}_{3} \mathrm{Ag}_{0.37} \mathrm{O}_{7}$ and $\mathrm{Ba}_{1} \mathrm{Ca}_{2} \mathrm{Cu}_{3} \mathrm{Ag}_{0.37} \mathrm{O}_{6}$ were prepared by aerosol decomposition. An aqueous solution of $\mathrm{Ba}, \mathrm{Ca}$, $\mathrm{Cu}$ and $\mathrm{Ag}$ nitrates with stoichiometry $\mathrm{Ba}: \mathrm{Ca}: \mathrm{Cu}: \mathrm{Ag}=$ 2(or 1):2:3:0.37 ( 5 weight $\% \mathrm{Ag}$ in fully reacted powder) and a $\mathrm{Cu}^{2+}$ concentration of $0.1 \mathrm{M}$ was prepared by dissolving $\mathrm{BaCO}_{3}, \mathrm{CaCO}_{3}, \mathrm{CuO}$ and $\mathrm{AgNO}_{3}$ in $\mathrm{HNO}_{3}$. The $\mathrm{pH}$ of the solution was approximately 1. An aerosol was generated from the precursor solution using a commercial atomizer and was carried through an alumina reactor tube which is kept inside a tube furnace. The furnace was maintained at a temperature of $850^{\circ} \mathrm{C}$, and the flow was adjusted to obtain residence times of 1-25 sec within the decomposition zone, and the oxide powders were collected on a silver membrane filter. Argon-oxygen (2\%) gas was used the carrier gas. A schematic diagram of the powder generation apparatus is shown in Figure 1. Pyrolysis temperature, residence time and carrier gas compositions were the key process parameters for the aerosol decomposition. Typical collection rates of the powders were about $1 \mathrm{~g} / \mathrm{h}$. Exposure of the powder on the filter to water or high humidity must be avoided. To prevent condensation and to reduce the relative humidity during powder collection, the filter was heated to $60-70^{\circ} \mathrm{C}$. The powders were unloaded from the filter inside a dry box. The precursor powders were then post-annealed in $0.1 \mathrm{~atm}$ of oxygen at $700^{\circ} \mathrm{C}$ for $4 \mathrm{~h}$ to reduce the level of carbon present. Annealing in high purity oxygen gas was found to be crucial. The precursor powders were then mixed with $\mathrm{Tl}_{2} \mathrm{O}_{3}$ with the typical composition of $\Pi_{x} ; x=0.6-1.0$, sealed in a gold tube and heat-treated in flowing oxygen between $650-890^{\circ} \mathrm{C}$ for various reaction times. The details of the starting nominal compositions, reaction temperatures, and reaction times are reported in Table I. 


\section{DISCLAIMER}

Portions of this document may be illegible in electronic image products. Images are produced from the best available original document. 
TABLE I

Summary Of Various T-Phases Obtained From Ba-Ca-Cu-Ag-O Based aerosol Precursor Powders

\begin{tabular}{|c|c|c|c|c|}
\hline $\begin{array}{l}\text { S. } \\
\text { No. }\end{array}$ & Starting Nominal Compositions ${ }^{a}$ & $\begin{array}{l}\text { Reaction } \\
\text { Temp. } \\
\text { ('C) }\end{array}$ & $\begin{array}{l}\text { Reaction } \\
\text { Time } \\
\text { (b) }\end{array}$ & XRD Results \\
\hline \multirow[t]{2}{*}{1.} & \multirow{2}{*}{$\mathrm{T}_{1.00} \mathrm{Ba}_{1.05} \mathrm{Ca}_{2.02} \mathrm{Cu}_{3.00} \mathrm{Ag}_{0.32} \mathrm{O}_{\mathrm{y}}$} & $650-775$ & 12 & $\pi 7.2212$ \\
\hline & & $\begin{array}{l}800-830 \\
850-880 \\
890\end{array}$ & $\begin{array}{c}6 \\
3 \\
0.50\end{array}$ & $\begin{array}{l}\mathrm{T} 1-2212 \\
\mathrm{~T} 1-2223 \\
71-2223\end{array}$ \\
\hline 2. & $\mathrm{Tl}_{0.80} \mathrm{Ba}_{1.05} \mathrm{Ca}_{2.02} \mathrm{Cu}_{3.00} \mathrm{Ag}_{0.32} \mathrm{O}_{\mathrm{y}}$ & 850 & 0.50 & T7-2223 \\
\hline 3. & $\mathrm{Tl}_{0.60} \mathrm{Ba}_{1.05} \mathrm{Ca}_{2.02} \mathrm{Cu}_{3.00} \mathrm{Ag}_{0.32} \mathrm{O}_{\mathrm{y}}$ & 840 & 0.33 & T1-1223;11-2223 \\
\hline \multirow[t]{2}{*}{4.} & \multirow[t]{2}{*}{$\mathrm{Tl}_{1.00} \mathrm{Ba}_{1.92} \mathrm{Ca}_{2.10} \mathrm{Cu}_{3.00} \mathrm{Ag}_{0.36} \mathrm{O}_{y}$} & 650 & 2 & $\mathrm{~T} 7-1212 ; \mathrm{T1}-2212$ \\
\hline & & $\begin{array}{l}750-830 \\
850-880\end{array}$ & $\begin{array}{l}1 \\
1\end{array}$ & $\begin{array}{l}\mathrm{T} 7-2212 \\
\mathrm{~T}-2223\end{array}$ \\
\hline 5. & $\mathrm{~T}_{0.80} \mathrm{Ba}_{1.92} \mathrm{Ca}_{2.10} \mathrm{Cu}_{3.00} \mathrm{Ag}_{0.36} \mathrm{O}_{\mathrm{y}}$ & 850 & 1 & $\mathrm{~T} 7-2223$ \\
\hline \multirow[t]{2}{*}{6.} & \multirow[t]{2}{*}{$\mathrm{Tl}_{0.80} \mathrm{Ba}_{2.00} \mathrm{Ca}_{2.00} \mathrm{Cu}_{3.00} \mathrm{Ag}_{0.40} \mathrm{O}_{y}$} & $650-700$ & 1 & $\mathrm{Tl}-1223 ; \mathrm{Tl}-1212$ \\
\hline & & $\begin{array}{l}750-800 \\
830-865\end{array}$ & $\begin{array}{l}1 \\
1\end{array}$ & $\begin{array}{l}\text { Tl-2212 } \\
\text { Tl-2223 }\end{array}$ \\
\hline
\end{tabular}

asome of the compositions were determined from ICP analysis.

bonly major phases are reported

The samples were characterized by $\mathrm{X}$-ray powder diffraction (XRD). Carbon content was determined by the LECO Carbon analyzer and chemical compositions were determined by ICP. Grain morphology and grain size were obtained using scanning electron microscopy (SEM).

\section{RESURTS AND DISCUSSION}

The room-temperature X-ray powder pattern for the $\mathrm{Tl}$ free precursor powders showed the presence of $\mathrm{BaCuO}_{2}$, $\mathrm{CaO}, \mathrm{CuO}$ and $\mathrm{Ca}-\mathrm{Cu}-\mathrm{O}$ phases. The SEM micrograph of the $\mathrm{Ba}_{2} \mathrm{Ca}_{2} \mathrm{Cu}_{3} \mathrm{Ag}_{0.37} \mathrm{O}_{7}$ precursor powder is shown in Figure 2. The as-produced powders are homogeneous hollow spheres which are less than a micron in size. The carbon content for

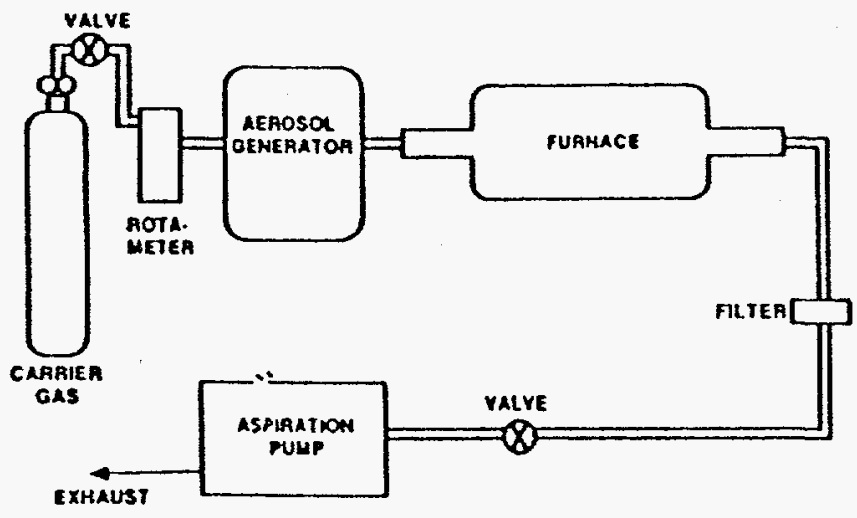

Fig. 1. Schematic diagram of the aerosol pyrolysis system. the as-produced aerosol precursor powders was of the order of $5000 \mathrm{ppm}$. After post-annealing at $700{ }^{\circ} \mathrm{C}$ in $0.1 \mathrm{~atm}$ oxygen for $4 \mathrm{~h}$, the carbon content was reduced to $2000 \mathrm{ppm}$.

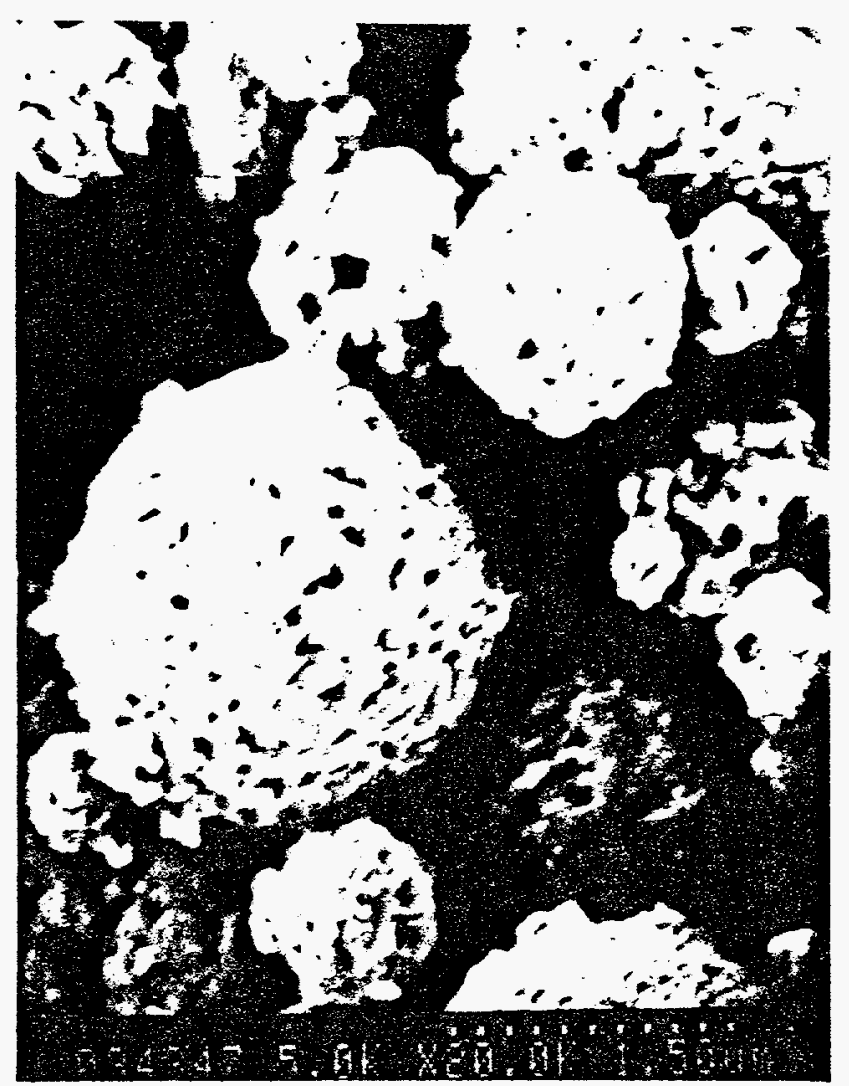

Fig. 2. Typical SEM micrograph of the as-produced aerosol precursor powders illustrating the presence of submicron size particles. 


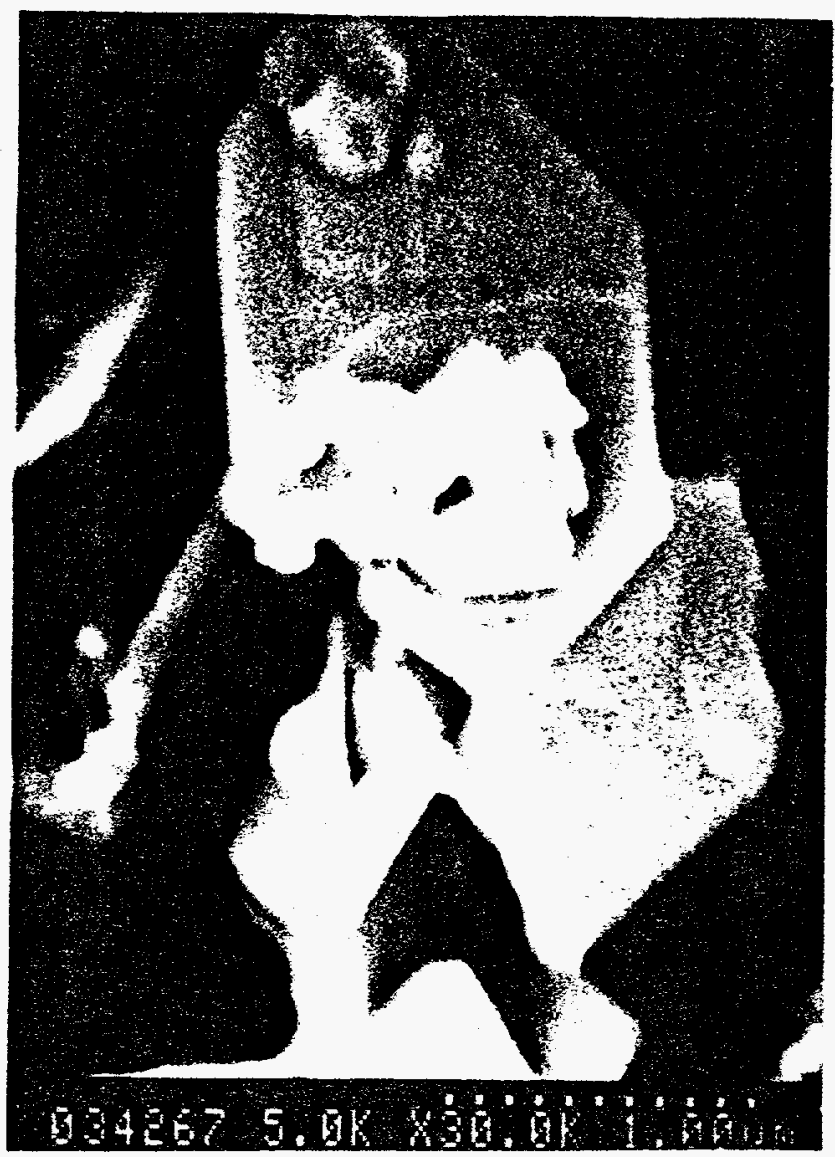

Fig. 3. SEM micrograph of the mixture of $71-1212$ and $T 7-1223$ superconductors.

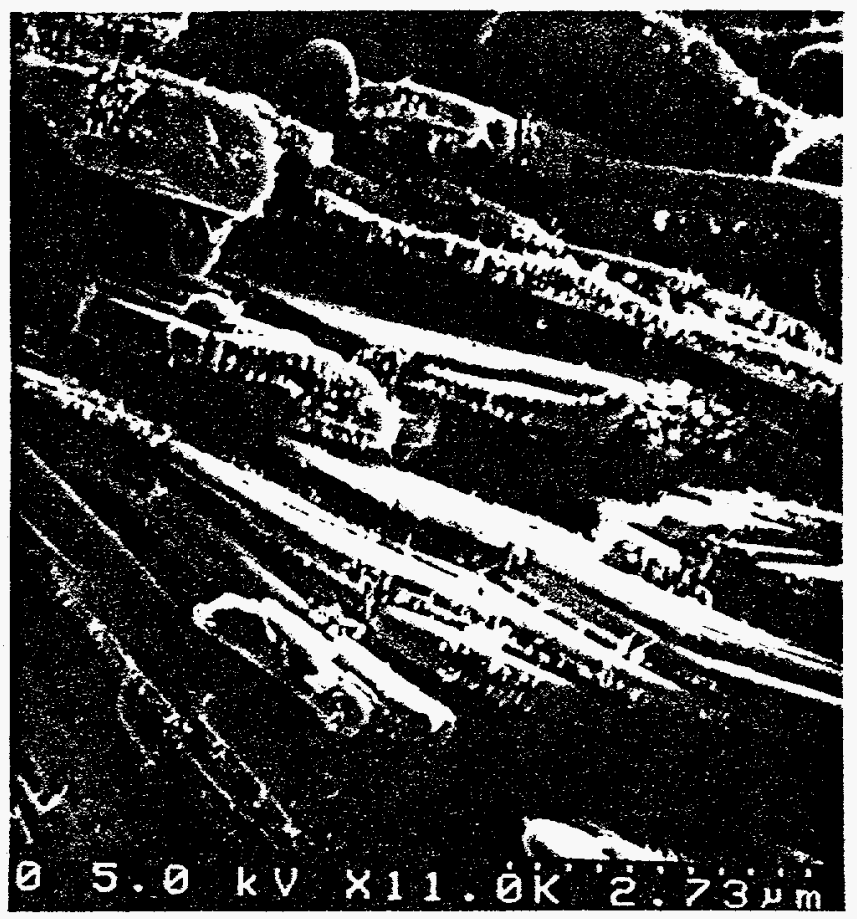

Fig. 4. SEM micrograph of the T $T-2212$ superconductor.
The room-temperature XRD results for the heat-treated T7containing precursor powders are reported in Table I. In addition to the major phases reported, minor impurities such as $\mathrm{BaCuO}_{2}, \mathrm{CaO}$ and $\mathrm{CuO}$ were also observed. In general, T1-1212 and Tl-1223 phases formed below $700^{\circ} \mathrm{C}$ while Tl2212 formed between $700-830^{\circ} \mathrm{C}$, and $\mathrm{Tl}-2223$ fonned above $830^{\circ} \mathrm{C}$. The SEM micrographs for the mixture of T1-1212 and $\mathrm{Tl}-1223, \mathrm{Tl}-2212$, and $\mathrm{Tl}-2223$, are shown in Figures 3, 4 , and 5 respectively. These SEM micrographs clearly show the evidence for formation of highly anisotropic platelets. The Tl-2212 and Tl-2223 phases were stable over a wide range of temperatures.

We demonstrated the formation of various $\mathrm{Tl}$ phases from 1223 (or 1123) starting compositions at different processing temperatures. Efforts are being made to use these platelets for various conductor fabrication routes. Bayya et al. [6] also obtained highly anisotropic particles of T1-2212 and Tl-2201 from the starting nominal compositions of 1223 by using $\mathrm{NaCl}-\mathrm{KCl}$ as a molten salt medium at $850^{\circ} \mathrm{C}$ with a reaction time of $1 \mathrm{~h}$.

\section{ACKNOWLEDGMENT}

M. P. thanks D. B. Beach for encouragement and Huey Hsu for belpful discussions.

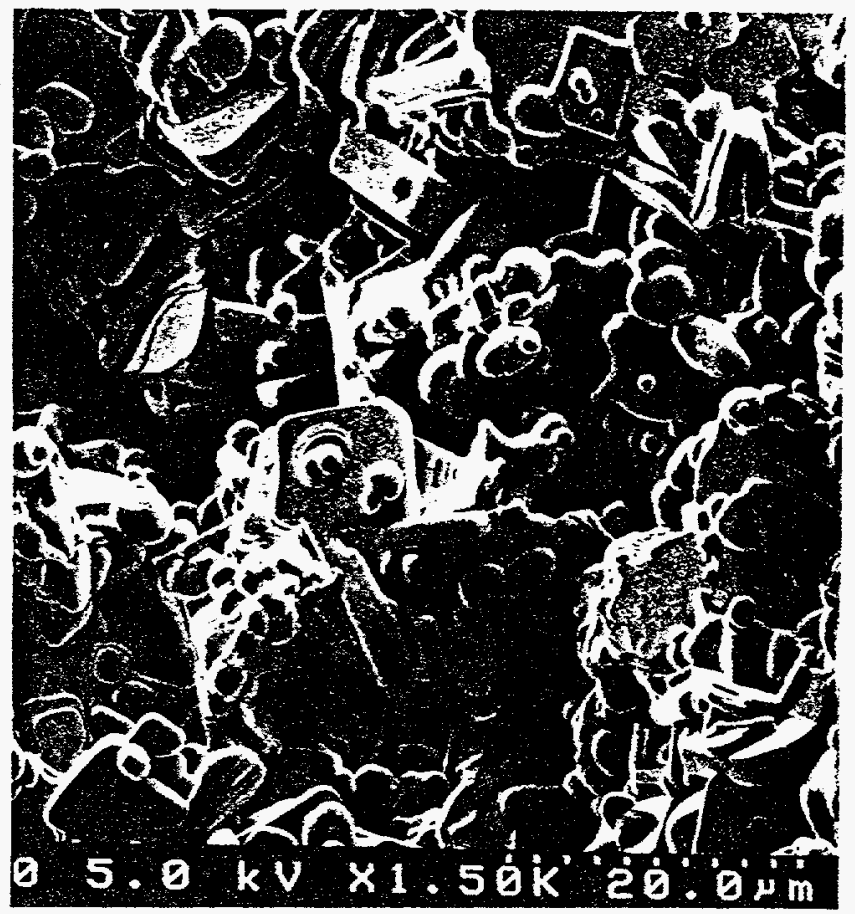

Fig. 5. SEM micrograph of the T7-2223 superconductor illustrating the platelet formation. 


\section{REFERENCES}

[1] D. H. Kim, K. E. Gray, R. T. Kampwirth, J. C. Smith, D. S. Richeson, T. J. Marks, J. H. Kang, J. Talvacchio, and M. Eddy, "Effect of $\mathrm{Cu}-\mathrm{O}$ layer spacing on the magnetic field induced resistive broadening of high-temperature superconductors," Physica C, vol. 177, pp. 431-437, 1991.

[2] T. Doi, T. Nabatame, T. Kamo, and S. P. Matsuda, "Introduction of pinning centers in Tl-based 1212 and 1223 superconductors: bulk and thin films," Supercond. Sci. Technol., vol. 4, pp. 488-490, 1991.

[3] J. A. DeLuca, P. L. Karas, C. L. Briant, J. E. Tkaczyk, and A. Goyal, "Progress in the development of the silver addition process for preparing textured " 1223 " T1-Ca-Ba -Cu-oxide thick films," Processing of Long Lengths of Superconductors, U. Balachandran, E. W. Collings, and A. Goyal, Eds., The Minerals, Metals \& Materials Society, 1994, pp. 231-240.
[4] D. M. Kroeger, A. Goyal, E. D. Specht, Z. L. Wang, J. E. Tkaczyk, J. A. Sutliff, and J. A. DeLuca, "The pach for long range conduction in high $\mathrm{J}_{\mathrm{c}} \mathrm{TlBa} \mathrm{Ca}_{2} \mathrm{Cu}_{3} \mathrm{O}_{8+x}$ spray-pyrolyzed deposits," Processing of Long Lengths of Superconductors, U. Balachandran, E. W. Collings, and A. Goyal, Eds., The Minerals, Metals \& Materials Society, 1994, pp. 289-297.

[5] S. Chadda, T. L. Ward, A. Carim, T. T. Kodas, K. Ott, and D. M. Kroeger, "Synthesis of $\mathrm{YBa}_{2} \mathrm{Cu}_{3} \mathrm{O}_{7-\mathrm{x}}$ and $\mathrm{YBa}_{2} \mathrm{Cu}_{4} \mathrm{O}_{8}$ by aerosol decomposition," J. Aerosol Sci., vol. 22, pp. 601-616, 1991.

[6] S. S. Bayya, C. Park, and R. L. Snyder, "Molten salt powder synthesis in the development of practical superconductors," Processing of Long Lengths of Superconductors, U. Balachandran, E. W. Collings, and A. Goyal, Eds., The Minerals, Metals \& Materials Society, 1994, pp. 185-194 and references therein.

\section{DISCLAIMER}

This report was prepared as an account of work sponsored by an agency of the United States Government. Neither the United States Government nor any agency thereof, nor any of their employees, makes any warranty, express or implied, or assumes any legal liability or responsibility for the accuracy, completeness, or usefulness of any information, apparatus, product, or process disclosed, or represents that its use would not infringe privately owned rights. Reference herein to any specific commercial product, process, or service by trade name, trademark, manufacturer, or otherwise does not necessarily constitute or imply its endorsement, recommendation, or favoring by the United States Government or any agency thereof. The views and opinions of authors expressed herein do not necessarily state or reflect those of the United States Government or any agency thereof. 